\title{
Marka İşbirlikleri İçin Yeni Bir Alan: Youtube İçerik Üreticileri ve Kanal Toplulukları Üzerine Netnografik Bir Araștırma
}

\author{
Begüm Mutlu' \\ Selçuk Bazarcl ${ }^{2}$ \\ Öz
}

Teknoloji devrimi ve sosyal medyanın gelişimi, tüketicilere iletişim araçları karşısında seslerini duyurabilme imkânı vermekle kalmamış, onları yeni medya araçlarında paylaşılan içeriklerin kaynağı konumuna getirmiştir. Yeni medya araçları kullanımı beceresine sahip, bu araçlar vasıtası ile içerik oluşturan, oluşturduğu içeriği paylaşan ve kendilerine ait bir hedef kitleye sahip olan yeni tüketiciler, reklamcılık açısından değerlendirildiğinde markaların hedef kitlelerine ulaşabilmesi için önemli bir konumda yer almaktadır.

Bu çalışma, temel hedefi içerik üreticilerin sahip olduğu kanal topluluğu ile bağlantı kurmak olan YouTube içerik üreticileri marka işbirliği videolarını ele almaktadır. Araştırmanın amacı markaların stratejik hatalarını engellemek için gerçekleştirilen işbirliği videolarının YouTube kanal toplulukları tarafından nasıl karşılandığını ortaya koymaktır. 3 Kasım 2013 tarihinde YouTube'a katılmış olan ve 11 Mayıs 2016 tarihi itibari ile 434.305 abonesi bulunan "Duygu Özaslan" adlı makyaj kanalı araştırmanın örneklemi olarak belirlenmiştir. Kanal topluluğunun yapısını belirleyebilmek için ilgili YouTube kanalında yer alan videolara 4 Ekim 2015 - 11 Mayıs 2016 tarihleri arasında yapılmış 1.502 yorum, nitel bir araştırma deseni olan netnografi kullanılarak analiz edilmiştir. Yapılan analizler sonucunda kanal topluluğunda üç farklı üye tipinin yer aldığı ve farklı video içerikleri karşısında üye oldukları grup özelliklerine göre tepkiler verdikleri tespit edilmiştir. Araştırma sonuçları, ilgili YouTube içerik üreticisi ile işbirliği gerçekleştirecek markaların, hedef kitle belirleme sürecinde kanal topluluğundaki farklı grupların özelliklerini göz önünde bulundurmaları gerektiğini göstermektedir.

Anahtar Kelimeler: Marka İşbirliği, YouTube, YouTube Ünlüleri, Sanal Topluluklar, Netnografi, Sosyal Medya Pazarlaması

\section{A New Area For Brands Collaborations: A Netnographic Study On Youtube Content Creators And Channel Communities}

\author{
Abstract \\ 1 Ege Üniversitesi Sosyal Bilimler Enstitüsü - Reklamcılık Anabilim Dalı \\ 2 Araş. Gör., Ege Üniversitesi Sosyal Bilimler Enstitüsü - Reklamcılık Anabilim Dalı
}

The technological revolution and the development of social media have not only enabled consumers to be heard via communication tools, but also made them a source of content shared in the new media tools. New consumers, who have the ability to use, 
create content with new media tools, share their contents and have a target group of their own, have an important role in terms of advertisement in reaching the target groups of brands.

This study focuses on the brands collaborations of YouTube content creators and cobranded video channels. The purpose of the study is to reveal the perception of the YouTube channel communities concerned with contracted video contents to prevent strategic mistakes of the brand. The sample of this study is the make-up channel named by vlogger "Duygu Özaslan" that joins YouTube on November 3rd, 2013 and has 434,305 subscribers as of May 11th, 2016. In order to determine the structure of the relevant YouTube channel community, 1,502 comments made between October 4th, 2015 and May 11th, 2016 were analysed through netnography, a qualitative research design. As a result of the analysis, it was detected that three different member types participated in the channel community and responded to different video contents according to the group characteristics that they belonged to. Research results reveal that brands that collaborate with the relevant YouTube content creater need to consider the characteristics of different groups in the channel community during the target audience setting process.

Keywords: Brands Collaboration, YouTube, YouTube Celebrities, Online Community, Netnography, Social Media Marketing 


\section{Giriș}

$\mathrm{B}$ ugün tüm bireylerin iletişim kurma, haber alma, bilgi edinme gibi pek çok intiyacını karşılayan sosyal medyanın ortaya çıkışı, Web 2.0 teknolojilerinin gelişmesi ile mümkün olmuştur. 1979 yılında Duke Üniversitesi'nden Tom Truscott ve Jim Ellis'in internet kullanıcılarının kamuya açık mesajlar yayınlamasına izin veren dünya çapında bir tartışma sistemi yaratmasıyla, günümüz sosyal medya platformlarının temelleri atılmıştır (Kaplan ve Haenlein, 2010: 60). 1989 yılında Bruce ve Susan Albenson tarafından çevrimiçi günlük yazan kişileri bir toplulukta bir araya getiren "Open Diary" internet sitesinin kurulması ile birlikte sosyal medya çağı başlamıştır (Ertürk ve Ertem Eray, 2015: 75). Sosyal medya 'Web 2.0'ın ideolojik ve teknolojik temellerine dayandırılarak inşa edilen ve kullanıcı merkezli içeriğin yaratımı ile dağıtımına izin veren bir grup internet temelli uygulamalar" olarak tanımlanmaktadır (Kaplan ve Haenlein, 2010: 61). Sosyal medya platformlarını sahip olduğu içerikler ve kullanıcıya sunduğu işlevler açısından yedi başlık altında değerlendirmek mümkündür (Mayfield, 2008: 6):

\section{Sosyal Ağlar (Myspace, Facebook)}

2. Bloglar

3. Wikiler (Wikipedia)

4. Podcastler (Apple iTunes)

5. Forumlar

6. İçerik Toplulukları (Flickr, YouTube)

7. Microbloglar (Twitter)

Sosyal medyanın gelişmesi ve yayılması ile birlikte belli bir topluluk içerisinde fikirleri beğenilen, yaratıcı, kendi istediği içerik ve biçimde mesajı oluşturma ve yayma özgürlüğü olan bir kullanıcı ortamı yaratılmış ve her internet kullanıcısı birer içerik üreticisi konumuna gelmiştir (Yeygel Çakır, 2015: 243). Dyck'e göre günümüzde herkes herhangi bir konudaki görüşünü internet vasıtası ile ifade etmekte özgürdür. Bu bağlamda sosyal medya devriminin, kültür kralığının anahtarlarını uzmanlardan ve denetçilerden alıp sıradan insanların sesini duyurabilmesine imkân verdiğini söylemek mümkündür (2014: 78). Teknolojik değişimin, reklamcılık ve reklamcılar için sadece şekil değil, aynı zamanda içerik açısından da yeni güçlükler doğurduğunu belirten Dyck, artık yeni yol gösterici ilkelerin parçalanma, karşılıklı etkileşim, katılımcılık ve şeffaflık olduğunu; bunun da reklamcılık için işbirliği ve sürekli temas halinde kalma çağı olduğunu ifade etmektedir (2014: 14-15). Teknolojideki gelişmeler ve buna bağlı olarak tüketicilerdeki değişimler dikkate alındığında bir içerik paylaşım sitesi olan YouTube, gerek markaların yeni medya tüketim alışkanlıklarını benimsemiş hedef kitlelerine ulaşabilmeleri gerekse etkili iletişim stratejileri yaratabilmeleri için önemli mecra olarak değerlendirilebilir.

Araştırmanın amacı markaların stratejik hatalarını engellemek için YouTube içerik üreticileri ve markaların birlikte gerçekleştirdiği işbirliği videolarının YouTube kanal 
toplulukları tarafından nasıl karşılandığını ortaya koymaktır. Bu bağlamda öncelikle katılımcı kültür unsurlarının gözlemlenebildiği bir sosyal medya platformu olan YouTube'un ve içerik üreticilerinin, günümüz pazarlamasındaki önemine değinilecektir. Ardından Duygu Özaslan isimli YouTube içerik üreticisinin makyaj kanalının sahip olduğu topluluk yapısı, nitel bir araștırma deseni olan netnografi kullanılarak analiz edilecektir. Toplulukta yer alan üye tipleri belirlendikten sonra kanal topluluğunun YouTuber-marka işbirliği videoları karşısında verdikleri tepkiler incelenecektir.

\section{Bir Katılımcı Kültür Unsuru Olarak YouTube}

Amerikan medya uzmanı Henry Jenkins tarafından geliştirilen "katılımcı kültür" kavramı medyadaki değişimi ve bir video paylaşım sitesi olan YouTube'un işleyişini açıklamak için oldukça uygundur. Katılımcı kültür, günümüz tüketicilerinin video, fotoğraf, ses dosyaları gibi görsel ve işitsel içeriklerden oluşan kültürel malların üretilmesi, yayılması ve yorumlanması için bireysel olarak aktif rol alması şeklinde tanımlanmaktadır (Mueller, 2014: 5). Bu bağlamda YouTube, katılımcı kültür söylemlerinin gözlemlenebildiği ve günümüz güçlü tüketicisinin özgürce hareket edebileceği anahtar bir site olarak değerlendirilmektedir (Burgess ve Green, 2009: 89).

15 Şubat 2005’te 3 eski PayPal çalışanı tarafından kurulan ve Kasım 2006'da Google tarafından 1.65 milyar dolara satın alınan YouTube, günümüzde Google'ın yan kuruluşlarından biri olarak faaliyetleri sürdürmektedir. Google'dan sonra en çok ziyaret edilen ikinci site olan YouTube, kullanıcılarına video yükleme, izleme ve paylaşma imkânı sunmakta ve sitede genel olarak video klipler, televizyon klipleri, müzik videoları, video bloglar (vlog), kısa özgün videolar ve eğitim videoları gibi içerikler yayınlanmaktadır. YouTube vasıtası ile hem amatörler hem de profesyoneller içerik üretebilmekte, kendilerine ait kanal sahibi olabilmekte ve yorumlar vasıtası ile birbiriyle iletişime geçebilmektedir. Özgür hareket alanı vaadini gerçek kılması sebebiyle katılımcı kültür dinamiklerini harekete geçiren bir platform işlevini gören YouTube, aynı zamanda iletişimi kutuplaştıran tek tarafı ıapıyı tamamen ortadan kaldırarak mesaj ve içeriğin üretimindeki sabit noktanın kalkmasına da olanak sağlamaktadır. Çünkü kullanıcı tarafından oluşturulan içerik doğası gereği işbirliği ve katılımcı kültür bağlamında biçimsel olarak üretimi devam ettirici güçleri içerisinde barındırmaktadır. Jenkins bu durumu, yakınsama kavramıyla ilişkilendirmektedir. Özellikle kültürel anlamda gerçekleşen yakınsamayla birlikte çeşitli medya teknolojileri, endüstriler ve tüketiciler arasında internet bağlantılı yeni ilişkiler ve iletişim formları şekillenmektedir (2001: 93). Oluşan bu yeni ağ ile birlikte, bilgi akışkan ve etkin bir kimliğe bürünmekte; bilginin gücünün artması da toplumsal yapının değişmesine ve bu yapının elde edilen deneyimsel çıktılar noktasında evrilmesine neden olmaktadır.

Chau, temel olarak katılımcı kültürü karakteristik özelliklerini, YouTube açısından beş ana başlık altında değerlendirmektedir (2010: 67-68):

1. Sanatsal ifade ve sivil katılım için düşük engeller: YouTube bireylere hemen hemen istedikleri tüm içerikleri ve videoları internet ortamına yüklemek için bir özgürlük fırsatı tanımaktadır (Holmbom, 2015: 17). Özellikle topluluklara ve paylaşılan içeriklere ulaşmanın ücretsiz ve kolay olması hem kullanıcı ile YouTuber hem de kullanıcıların kendi aralarındaki iletişimde bariyerlerin düşük olmasına olanak tanır. Böylece genç bireylerin çevrelerini tanımaları, özgüven 
kazanmaları, kendi kimliklerini keşfetmeleri ve toplumsal süreçlere entegre olmaları kolaylaşmaktadır.

2. Bireyin projesini yaratması ve paylaşması açısından güçlü bir destek: Kullanıcının ilgisi ile bağlantılı olarak YouTube bazı grup ve topluluklarla ilgili bilgilendirmelerde bulunmaktadır. Bu tip öneriler vasıtasıyla topluluklara katılan kullanıcılar, etkileşimli bir sürecin içerisine doğrudan dâhil olmaktadır. Kullanıcıların topluluk söylemlerinin bir parçası olmaları ve kendi oluşturdukları içerikleri kolayca paylaşabilmeleri YouTube gibi platformlarda, bireyin kendisini o topluluğa ait hissetmesi ve topluluk kimliği kazanması adına önemlidir.

3. Gayrı resmi rehberlik: YouTube kanalları yeni katılan kullanıcılar için bir danışmanlık işlevi görür. İnformel olan bu rehberlik vasıtasıyla kullanıcıların yeni beceriler elde etmesi sağlanmaktadır.

4. Katkılara önemli bir inanç: YouTube'daki toplulukların evrilmesi ve gelişmesi adına paylaşımlara geri bildirim sağlayan katılımcıların katkıları çok kıymetlidir. Bir videoyu oylamak ve yorum yapmak içerik oluşturucunun yaptığı paylaşımlarıntşekillendirmesine yardımcı olmaktadır. Interaktif sürece katılan ve topluluk içerisinde birbirleriyle sosyalleşen katılımcıların topluluğa olan aidiyetleri de bu bağlamda güçlenmektedir.

5. Sosyal bağlantı duygusu: YouTube, bazı ilkel sosyal ağ özellikleri nedeniyle işbirliği ve senkronize etkileşimli bir web alanı olarak tasarlanmamıştır. Ancak genç YouTuberlar bazı yenilikçi yöntemlerle birbirlerini desteklemekte ve işbirliğine teşvik etmektedir. Bu noktada katılımcı kültür bileşenleri açısından YouTube'un bir sosyal bağlantı aracı olduğu ve kullanıcılar tarafından oluşturulan kültürel çıktıları aktarmada bir mecra olarak işlevsellik sağladığını söylemek mümkündür.

Bu bağlamda YouTube yalnızca video paylaşımı yapılan ve içerik yayınlanan sanal bir platformdan daha fazlasını ifade etmektedir (Chau, 2010: 67). Kullanıcıların YouTube vasıtasıyla gerçekleştirdikleri davranış pratikleri göz önüne alındığında, katılımcı kültür özelliklerinin açık bir şekilde gözlemlenebildiğini söylemek mümkündür. Platform, bireylerin sosyal yaşama adaptasyonunda ve katılımcı kültüre dahil olmaları açısından önemli araçlardan biridir. Bireylerin gerçek yaşamlarında sahip oldukları sosyal statü ve rollerindeki farklılıklar gibi YouTube'da da kullanıcılarının siteyi kullanma biçimleri, sahip oldukları nitelikler ve site içinde üstlendikleri sosyal roller birbirinden farklıdır. Lange kullanıcılar arasındaki farklııklarla ilgili beş farklı kullanıcı tipinden bahsetmektedir. Kullanıcıların genel özellikleri ise şu şekildedir (2007: 4):

- Eski kullanıcılar: Video yüklemesi yapmayan, kendi hesapları üzerinden videolar izleyen ve arada bir videolara yorum yapan kullanıcılardır.

- Sıradan katılımcılar: Kendi hesabı bulunmayan, özel aramalar gerçekleştiren ve sitede gezinen kullanıcılardır.

- Aktif kullanıcılar: Kendi hesapları olan, genellikle video yükleyen, kendilerine ait video listeleri oluşturan, diğer kullanıcıların videolarına yorum bırakan ve YouTube kanallarına üye olan kullanıcılardır. Aktif katılımcılar YouTube topluluklarının önemli bir kısmını oluşturmaktadır. 
- YouTuberlar: Video yükleyen ve site içerisinde tartışmalara katılan, diğer kullanıcı tiplerine göre YouTube ile çok daha fazla ilgili olan kullanıcılardır. Kendilerini YouTube topluluğunun bir parçası olarak tanımlamaktadırlar.

- YouTube ünlüleri: Son grup olan YouTube ünlüleri, YouTuberlar ile ortak niteliklere sahiptir. YouTube ünlüleri kendilerini "YouTuber" olarak tanımlamaktadır. Ancak YouTube-ünlülerinin hem site kullanıcıları hem de diğer insanlar tarafından tanınması, söylemleri, amaçları, kendi videoları vasıtasıyla gerçekleştirdikleri aktiviteler, yorumlar, bültenler ve etkili bir iletişime sahip olmaları bu kullanıcıları YouTuberlardan ayıran belli başlı özelliklerdir. Bir içerik üreticisi, YouTube ünlüsü kategorisine erişebilmek için üç farklı aşamadan geçmektedir. Illk aşama olan ve kanal abone sayısı 5000'den daha az olan "Builders" içerik üreticilerin yüzde 89'unu oluştururken, abone sayısı 5.000 ile 100.000 arasında değişen ve içerik üreticilerin yüzde 9'unun yer aldığı "Trendsetter" kategorisi ikinci aşamayı temsil etmektedir. Üçüncü ve son aşama olan ve abone sayısı 100.000 'den fazla olan içerik üreticilerini temsil eden "Celebrities" kategorisi ile kullanıcıların sadece yüzde 2'lik bir diliminden oluşmaktadır (The World of YouTube, 2015: 3).

Jenkins ve arkadaşlarına göre katılımcı kültür özellikleri taşıyan günümüz dünyasında bireylerin bir kısmı sadece gezinecek; bir kısmı ise daha da derinlere inecektir. Yeteneklerde ustalaşan diğerler bireyler ise toplumda en değerliler olacaktır (2006: 8). Lange (2007)'ın araştırması sonucunda ortaya çıkan YouTube kullanıcı tipleri göz önüne alındığında YouTuberlar ve YouTube ünlüleri, katılımcı kültür özelliklerinin gözlemlenebildiği YouTube'da yeteneklerinde ustalaşan en değerli bireyleri temsil etmektedir.

\section{Sosyal Medya Pazarlamasının Yeni Yüzleri: YouTube İçerik Üreticileri}

Kullanıcı merkezli içerik üretim kültürünün birer parçası olan yüksek izlenme ve görünürlüğe sahip, "evde büyüyen (homegrown)" başarılı performans sergileyicileri ve üreticileri olan YouTube ünlüleri, ürettikleri içerikler ile girişimciliğin yeni modellerini ve kültürünü temsil etmektedirler (Burgess ve Green, 2009: 90-91). Çoğu içerik üreticisinin bir hobi olarak başladığı içerik üretme ve paylaşma süreci, bazı içerik üreticilerin YouTube ünlüsü haline gelmesi ve hobilerini bir işe dönüştürmesi ile sonuçlanmaktadır. Öyle ki bugün markaların YouTube'da başarılı olmaları için ilgili içerik üreticiler ile işbirliği yapmaları YouTube içerik stratejileri arasında yer almaktadır (The YouTube Creator Playbook for Brands, 2015: 15). "Markaların dijital etki sahipleri ile ortak bir çaba göstererek hazırladıkları içerik" olarak tanımlanan işbirliği videoları, YouTube içerik üreticisi ve üreticinin kanalı vasıtasıyla tanıtılmaktadır. Bu içerik türünün temel hedefi, markaların deneyimli içerik üreticilerinin uzmanlığından yararlanırken, üreticilerin sahip olduğu topluluk ile bağlantı kurmaktadır (Larson, 2016).

YouTube içerik üreticileri tarafından paylaşılan videolar, video blog ya da vlog olarak adlandırımaktadır. Vloglar, kullanıcı merkezli içerik üretiminin en baskın türü olmakla beraber, YouTube'un topluluk hissini anlamak için temel noktayı oluşturmaktadır (Burgess ve Green, 2009: 94). Genellikle bir kamera karşısında içerik üreticinin monolog şeklindeki iletişimi ile çekilen vloglar aracılığı ile aktarmak istedikleri mesajları kanal abonelerine ileten YouTube ünlülerinin mesajlarının ikna edici olabilmesi, videolarının izlenmesi ve abone sayılarının artması için birer kaynak olarak ikna edici bazı özellikler 
taşımaları gerekmektedir. Grapevine tarafından 1.861 içerik üreticisi ile gerçekleştirilen araştırmada, popüler YouTube içerik üreticileri ile YouTube'un 14-17 yaş arasındaki genç hedef kitlesi arasındaki ilişkiye dikkat çekilmektedir.

İlgili araştırmaya göre YouTube ünlüleri kategorisinde yer alan başarılı içerik üreticilerinin sadece \%20'si 14-17 yaş aralığındayken, bahsedilen üreticilerin \%57'si 24 yaşından daha büyüktür. Bu sebepler, popüler YouTuberlar genç hedef kitle tarafından birer rol model olarak algılanmaktadır (The World of YouTube, 2015: 7). Think with Google (2016) tarafından hazırlanan rapora göre ise, genç YouTube abonelerinin \%70'i, geleneksel ünlü kişilere oranla YouTube içerik üreticileri ile çok daha iyi ilişki kurabildiklerini, Y kuşağındaki 10 YouTube abonesinden 4'ü ise en sevdiği içerik üreticilerinin kendilerini arkadaşlarından daha iyi anladığını ifade etmektedir (www. thinkwithgoogle.com).

Burgess ve Green (2009)'nin “The Entrepreneurial Vlogger: Participatory Culture Beyond the Professional- Amateur Divide" adlı YouTube ünlüleri olarak adlandırılan girişimci YouTuberlar üzerine yaptıkları araştırma sonuçlarına göre, YouTube ünlüleri yalnızca başarılı kültürel girişimciler ve sanatçılar değil aynı zamanda diğer YouTube kullanıcıları için ortak bir kültürel kaynak ve YouTube içerisinde inşa edilmiş güçlü birer marka konumundadırlar. Sitenin dinamiklerinin, sadece üretici ve tüketici arasındaki ayrımı değil piyasa ve piyasa dışı sosyal ve ekonomik aktiviteler arasında gelişen ilişkiler üzerinde yıkıcı bir etkisi olduğunu belirten Burgess ve Green (2009), YouTube'da başarılı olmanın amatör ya da profesyonel olmakla değil; katılımcı bir medya unsuru olarak YouTube'un ne ölçüde anlaşıldığına ve sitenin dinamikleri ile uyumlu bir şekilde çalışmaya dayandığı sonucuna varmışlardır.

Bu bağlamda YouTube'un, kendine özgü kurallarını göz önüne alan ve iletişim çalışmalarını bu kurallara göre uygulayan markaların amaçlarına ulaşması kolaylaşabilecek iken; bu kuralları dikkate almayan markaların ise hedef kitle nezdinde inanılırlık ve samimiyet kaybı gibi pek çok olumsuz tepki ile karşı karşıya kalabileceklerini ve marka imajının zarar görebileceğini söylemek mümkündür.

Çalışmanın amacı markaların, YouTube içerik üreticileri ile birlikte hazırladığı işbirliği videolarındaki stratejik hataları engellemek için tüketicilerin bu videolar karşısındaki tepkilerini belirlemektir.

\section{Yöntem}

\subsection{Arastırmanın Problemi}

Markaların, YouTube içerik oluşturucuları ile birlikte hazırladıkları işbirliği videoları tüketicilerde nasıl bir tepki oluştur?

Alt Sorular

1. YouTuber'ın kendi segmentteki (fiyat, kalite) markalar ile gerçekleştirdiği işbirliği videoları karşısında tüketicinin tepkileri nasııdır?

2. YouTuber'ın alt segmentteki (fiyat, kalite) markalar ile gerçekleştirdiği işbirliği videoları kanal topluluğunun tepkisini nasıl etkiler? 


\subsection{Araștırmanın Deseni}

Markaların YouTube içerik üreticileri ile birlikte hazırladığı işbirliği videolarındaki stratejik hataları engellemek için tüketicilerin bu videolar karşısındaki tepkilerinin incelendiği çalışma nitel bir araştırmadır. İşbirliği videoları karşısında tüketicilerin tepkilerini belirleyebilmek için YouTube içerik üreticisinin kanal topluluğunun yapısının detaylı olarak incelenmesi gerekmektedir. Bu nedenle çalışmada nitel bir araştırma deseni olan netnografi kullanılmıştır. YouTube gibi dijital ortamda etkileşim kuran sosyal oluşumların, işlevsel ve samimi insan toplulukları olduğu anlayışından geliştirilen netnografi, geleneksel etnografyadan adapte edilmiştir. Pazarlama dünyasında çevrimiçi ağlardaki insan topluluklarının ortak bilinçlerine ve bilgi birikimlerine ulaşma imkânı veren netnografi, sosyal medyada platformlarındaki tüketici içgörülerinin incelenmesine olanak sağlayan nitel bir araştırma deseni olarak tanımlanmaktadır (Varnalı, 2013: 21-22).

Netnografi, çevrimiçi iletişimleri sadece içerik olarak değil, sosyal bir etkileşim, içinde anlam saklı ifadeler bütünü ve kültürel bir insan yapıtı olarak ele almaktadır. Bu nedenle yalnızca sosyal etkileşimlerde yer alan kelimelere değil, forumun öğeleri, iletişimcinin özellikleri, dil, geçmiş, anlam ve etkileşim biçimlerine bakarak fontları, boşlukları sembolleri, metinleri, fotoğrafları ve videoları incelenmektedir (Kozinets, 2010: 5). Tüketicilerin YouTuber-marka işbirliği videolarına tepkilerini yorum olarak bıraktıkları gözlemlenmiştir. Kanal topluluğunda yer alan üye tiplerinin belirlenebilmesi için yorumların detaylı olarak incelenmesi gerekmektedir. Bu nedenle nitel araştırma deseni olan netnografi çalışma için uygun bulunmuştur.

\section{3. Örneklem}

Nicel araştırmalara göre farklı felsefi ve kuramsal temellerden hareket eden nitel araştırmalar, elde edilen bulguları evrene genellemekten ziyade belli bir durumu derinlemesine incelemeyi hedeflemektedir. Bu nedenle araştırmanın örneklemi belirlenirken ölçüt örnekleme yöntemi kullanılmıştır. Amaçlı örnekleme yöntemlerinden biri olan ölçüt örneklemedeki temel anlayış önceden belirlenmiş bir dizi ölçütü karşılayan tüm durumların çalışılmasıdır. Burada bahsedilen ölçüt araştırmacılar tarafından belirlenebilmektedir (Yıldırım ve Şimşek, 2013: 130, 140).

"Duygu Özaslan" adı ile makyaj ve lifestyle video içeriklerinin yayınlandığı YouTube kanalına ait topluluğun yapısı, araştırmanın amacı olan kanal topluluklarının YouTuber ve marka işbirliği videoları karşısındaki davranışlarının incelenmesi açısından oldukça elverişli bir platform olarak dikkat çekmektedir. İlgili kanal, Türkiye'de faaliyet gösteren, makyaj ve lifesytle içerik üreten YouTube kanalları arasında en çok izleme ve takipçi sayısına sahip olmakla beraber Türkiye'de faaliyet gösteren tüm YouTube kanalları arasında 14. sırada yer almaktadır (www.boomsocial.com). Söz konusu kanalın 11 Mayıs 2016 itibari ile abone sayısı 414.000'dir. Veriler göz önüne alındığında ilgili YouTube kullanıcısı, araştırmanın literatür kısmında bahsedilen YouTube ünlüleri kategorisinde yer almaktadır.

Kanal topluluğuna üye olmak için bir Gmail hesabının olması ve bu hesap üzerinden siteye giriş yapılması yeterlidir. Bu giriş yapıldıktan sonra video içeriklerinin alt kısmında yer alan "Abone Ol” tuşuna tıklanarak kanala üye olabilmek ve Gmail hesabı 
ile üyesi olunan kanala video yüklendiğinde bilgilendirme maili alabilmek mümkün hâle gelmektedir. Duygu Özaslan adlı YouTube kanalında makyaj, cilt bakımı, saç modelleri, her ay YouTuber'ın kullandığı favori ürünlerin anlatıldığı, mezuniyet veya yılbaşı makyajı, moda, YouTuber'ın özel hayatı, alışveriş ve bu ürün gruplarında pazar ortamında faaliyet gösteren markalar ile yapılan işbirlikleri gibi pek çok farklı içeriğe sahip video paylaşılmaktadır.

Araştırmanın alt sorularına cevap verilebilmek için içerik üreticisinin YouTube kanalına Ekim 2015’te bir hafta ara ile yüklenmiş, ikisi işbirliği videosu biri sponsorsuz video içeriği olmak üzere toplamda üç farklı video seçilmiştir. Seçilen üç farklı video içeriğine yönelik toplam 1.502 adet kullanıcı yorumu bulunmaktadır. Bu sayede kanal topluluğunun sponsorsuz video içeriği ve işbirliği videosu karşısında farklı tepkilere sahip olup olmadığı ve farklı segmentteki işbirlikleri karşısında topluluğun nasıl bir tepki geliştirdiği belirlenebilecektir. Kanal topluluğunun yapısını ve işbirliği videolarına yönelik topluluğun tepkilerini belirlemek için analiz edilecek yorumların yer aldığı üç video sırasıyla şu şekildedir:

Video 1 (sponsorsuz video içeriği): HD Makyaj I Fotoğraf, Kamera Makyajı (https://www.youtube.com/watch?v=rtE9OXqdjGE)

Video 2 (YouTuber'ın kendi segmentindeki bir marka ile gerçekleştirilen işbirliği videosu):Yeni Sezon Alışverişim I Forever New I ad (https://www.youtube.com/ watch?v=DfvBhj6cln4)

Video 3 (YouTuber'ın alt segmentindeki bir marka ile gerçekleştirilen işbirliği videosu): Gül Kurusu Makyaj I 2000 Big\&False Lash Maskara Hediye I ad (https://www.youtube.com/watch?v=2JcarFNJ7B0)

\subsection{Güvenirlik ve Geçerlik}

Netnografi deseninde topluluk yapısını detaylı bir biçimde inceleyebilmek için en az 6 ayı kapsayan bir veri setine sahip olmak gerekmektedir. Örneklemde yer alan üç videonun da Ekim 2015 ayı içerisinde birer hafta ara ile yüklenmiş olması derinlemesine bir analizde gerekli olan veri zenginliğini sağlamaktadır. Veri zenginliğini koruyabilmek adına 4 Ekim 2015 tarihinden 11 Mayıs 2016 tarihine kadar üç videoya yapılmış olan 1.502 yorum analiz edilmiş ve üyelerin her durumda verdikleri tepkiler Ek 1'deki kod listesine dahil edilmiştir. Kodlama süreci ise iki aşamalı olarak gerçekleştirilmiştir. Birinci aşamada Ek 1'de yer alan kod listesine bağlı kalınarak tüm yorumlar analiz edilmiştir. İkinci aşamada ise her yorumun hangi üye tipine ait olduğu kodlanmıştır.

Aynı süreç araştırmacılar kodlamayı bitirdikten iki hafta sonra tekrarlanmıştır. Iki ayrı zamanda yapılan kodlama sonucunda analizler karşılaştırılmış ve verilerin analizi tamamlanmıştır. Bununla birlikte 1.502 yorum, excel tablosu şeklinde hazırlanan kod listesi doğrultusunda bilgisayar ortamına işlenmiştir. Bu sayede hem videolar hem de üye tipleri arasındaki farklılıklar detaylı olarak karşılaştırılmış ve incelenmiştir. Bulgular ve yorum bölümünde yer verilen kullanıcı yorumları üzerinde araştırmacılar tarafından herhangi değişiklik yapılmamıştır.

Etik bir ihlale yol açmamak için YouTube içerik üreticisine çalışma tamamlandıktan 
sonra bilgi verilmiştir. Aynı zamanda araştırmanın bir kopyası, içerik üreticisinin çalıştığı ajansın müşteri ilişkileri bölümüne e-posta yolu ile gönderilmiştir.

\title{
3.5. Araștırmacının Rolü
}

Araştırmacılar, Duygu Özaslan adlı YouTube kullanıcısını yaklaşık olarak bir yıla aşkın süredir takip etmektedir. Ancak araştırma dahilinde topluluk yapılarına etki etmemek ve topluluğu doğal ortam içerisinde gözlemleyebilmek için hiçbir şekilde kullanıcılar ile iletişime girmemiş ve örneklem dahilindeki videolara yorum yapmamıştır. Uzun süredir kanal abonesi olmaları, araştırmacılara YouTube dinamiklerine hâkim olma becerisi kazandırmış, bu nitelik araştırmanın veri analizi ve elde edilen verilerin yorumlanması aşamasında araştırmacılara kolaylık sağlamıştır.

\section{Bulgular ve Yorum}

\subsection{Kanal Topluluğu ve Üye Tipleri}

Araştırmanın alt sorularına cevap vermek için seçilen üç videoda yer alan 1.502 adet kullanıcı yorumu analiz edildiğinde Duygu Özaslan adlı YouTuber'ın kendi adıyla içerik ürettiği YouTube kanalının üç farklı üye tipine sahip olduğu sonucuna varılmıştır. Hayranlar $(H)$, doğrucular (D) ve sevmeyenler (S) olarak belirlenen üye tipleri ve özellikleri ise şu şekilde şekildedir:

\subsubsection{Hayranlar (H)}

Bu gruba dahil olan topluluk üyelerinin büyük çoğunluğunun yaş aralığı düşük olmasına rağmen YouTuber'a her konuda destek oldukları ve YouTuber'ı sahiplenme eğiliminde oldukları belirlenmiştir. Sahip oldukları bu eğilim dolayısıyla YouTuber'a yöneltilen çoğu soruya ve eleştiriye hayranlar tarafından cevap verilmektedir. Örneğin Video 1 'de YouTuber'ın fiziksel özellikleri ile ilgili doğrucular grubundaki bir üyeden gelen bir yoruma karşı hayranlar grubundaki üyenin geliştirdiği diyalog şu şekildedir:

\author{
"Çillerin artmış" [D, V1] \\ "Çilleri daha önce ilk başladığında vardı. Fakat sonraları sanki video \\ net göstermediğinden fazla belli olmuyordu..." [H, V1]
}

İdol olarak gördükleri YouTuber'ın hayatının bir parçası gibi davranan hayranlar bu nedenle YouTuber'ın özel hayatı ile ilgi bilgi sahibi olma konusunda oldukça istekli bir yapı sergilemektedirler. "Duygu abla, ablacım, canım ablam" şeklinde hitap şekilleri kullanan üyeler YouTuber ile iletişim kurmak için ricada bulunmakta, şikâyet ederken bile kibar bir tavır sergilemektedir. Ayrıca kullanıcıların YouTuber'a sık sık iltifat ettikleri görülmektedir. YouTuber'a yönelik olumsuz bir eleştiri karşısında saldırgan bir tutumu tercih eden hayranların sıkça Türkçe dilbilgisi kurallarını ihlal ettikleri, kısaltmalar ve dijital simgeler kullanma eğiliminde oldukları tespit edilmiştir. Aynı zamanda hayranlar grubunun diğer kullanıcılardan farklılaşmaya istekli ve öne çıkma çabasına sahip oldukları görülmüştür:

"ilk yorum makyajın coksel askimm" [H, V1]

"Kim almayada izliyor (Ben anlamına gelen dijital simge)" [H, V2]

"Hastayken bile izliyorum seni” [H, V3] 


\subsubsection{Doğrucular (D)}

Hayranlar grubu ile karşılaştırıldığında gerek YouTuber'a yönelik ifadeler de gerekse kendi aralarındaki iletişimde samimi ancak seviyeli bir dil kullanan doğrucular grubu üyelerinin, olumlu ya da olumsuz fikirlerini paylaşmaktan çekinmedikleri belirlenmiştir. Kendi aralarında haberleşme eğilimi olan bu grup üyeleri, daha objektif bir yapı sergilemektedir. Belirli kriterlere sahip olan doğrucular, yorumlarda kriterlerini belirtmekte ve yorumlarının sebeplerini açıklama davranışı göstermektedir:

"saçların ya yağlanmış yada kuru şampuan kullanmışsın heralde ama olmamış eğer kullandiysan markasını değiştirmeni öneririm..." $[\mathrm{D}, \mathrm{V} 2]$ "o kadar uzun saçın bakımı zordur tabi ve hoş durmuyor tabi" [D, V2]

\subsubsection{Sevmeyenler (S)}

YouTuber ve özellikle hayranlar ile dalga geçme eğilimine sahip olan bu grup, YouTuber'ın bir açığını yakaladıkları takdirde sert bir şekilde yorum yapmaktan geri durmamaktadır:

"yaw he he herkes ilk yorum yazmış garip insancıklar sizi :D:D:D" $[S, \mathrm{~V} 3]$

Hayranlar ve doğrucular gruplarına mensup olan üyelerin övgü ya da beğeni ile bahsettiği durumlar karşısında saldırgan bir tutum sergileyen sevmeyenler grubu üyelerinin, bu tutumlarının diğer gruplardan ziyade YouTuber'a yönelik olduğu belirlenmiştir. Mesaj kaynağı özelliği taşıyan YouTuber'ın gerek reklamsız gerekse sponsorlu videolarında bahsettiği ürünü veya markayı beğenseler dahi YouTuber'ı eleştirmektedirler:

"Duygu 50 kilo makyaj 55 kilo" [S, V1]

"Benim merak ettiğim sey yapmacik hareketlerinden kendin de hic sıkılmıyor musun acaba?" [S, V3]

Araştırmanın bir sonraki kısmında nitel veri analizi sonucunda ulaşılan kanal topluluğunun ve üye yapılarının, alt problemlerle ilişkilendirilerek elde edilen temalara ve ilgili kodlara göre nasıl tepkiler verdikleri sunulmaktadır. Araştırmanın alt problemlerini cevaplayabilmek adına en az iki videoda aynı kod ile ilişkilendirilebilen yorumlar dikkate alınmış; veri analizinin bu sınırlıı̆a sahip olması sayesinde grupların farklı içerikler karşısında sergiledikleri tutumları incelemek mümkün hale gelmiştir.

\subsection{YouTuber Marka İșbirliği Videolarına Yönelik Kullanıcı Tepkileri}

Araştırmanın alt problemleri 'YouTuber'ın kendi segmentteki (fiyat, kalite) markalar ile gerçekleştirdiği işbirliği videoları karşısında tüketicinin tepkilerini nasıldır?" ve "YouTuber'ın alt segmentteki (fiyat, kalite) markalar ile gerçekleştirdiği işbirliği videoları kanal topluluğunun tepkisi nasıl etkiler?" şeklinde ifade edilmiştir. Yapılan veri analizi sonucunda kanal topluluklarının işbirliği videoları karşısında YouTuber'a destek 
olma, videolarından rahatsız olma, videoların içeriğine inanmama ve videoları normal karşılama şeklinde davranışlar sergiledikleri belirlenmiştir.

\section{3. İșbirliği Videosundan Rahatsız 0 lma}

Analizler sonucu belirlenen tüm grupların işbirliği videolarından rahatsız olduklarını dile getirdikleri ancak bunları grup özelliklerine uygun olarak farklı üsluplar ile ifade ettikleri belirlenmiştir. YouTuber'ı benimsemiş olan hayranlar grubunun rahatsızlıklarını daha ılımlı bir üslup ile ifade etme eğilimine sahip oldukları görülmektedir:

"Duygu abla sen cidden çok degistin ilk videolarındaki samimiyetinle yeni gelen videolarini karsilastiramırum bile (bence eski haline dönmelisin "bence'"' $[\mathrm{H}, \mathrm{V} 2]$

"çok sponsorlu video sıkıldık artık nolur (kalp)" [H, V3]

"tam mutlu oldum oh reklamsız video diye ve tabiki hayır" [H, V3]

Hayranlar grubuna dahil olan üyeleri, YouTuber'ın çok fazla işbirliği video içeriği paylaştığını ve gitgide samimiyet hissinin ortadan kalktığını düşündüklerini bu nedenle de videolardan rahatsız olduklarını ifade etmektedirler. Doğrucular grubu üyeleri de aynı sebepten dolayı videolardan rahatsız olduğu gözlemlenmektedir. Grup üyelerinin videolar karşısında verdikleri tepkiler şöyledir:

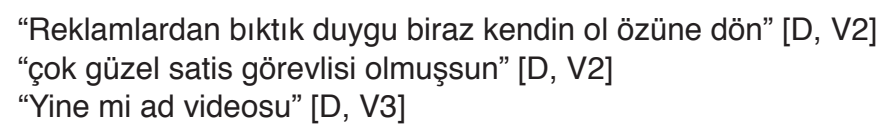

Doğrucular grubu üyeleri YouTuber marka işbirliği videolarından rahatsız olduklarını hayranlar grubuna göre daha sert bir üslup ile ifade etmişlerdir. Ayrıca grup üyelerinin bir kısmı YouTuber'ın kendi segmentinden, orta gelir seviyesinin üzerinde satın alım gücüne sahip tüketicilerin ulaşabileceği bir marka ile gerçekleştirdiği işbirliği videosu olan Video 2'ye eleştiriler bir tavır ile yaklaşmış ve videoda gerçekleştirilen alışverişin gereksiz ve çok pahalı olduklarını belirten ifadeler kullanmışlardır:

"Abi yapmayın allaskina bu ulkenin neredeyse yarisindan fazlasi kisin elektrik faturasını ödeyemediği icin sogukta kalan, asgari ucretle gecinen veya onu bile kazanamayan insanlardan olusuyo bi alısveris videosu yapmıs eve 5 aylik yiyecek stogu yaparsınız..." [D, V2]

YouTuber'ın açığını yakalama ve içerik üretici ile dalga geçme eğilimine sahip olan sevmeyenler grubu üyelerinin işbirliği videolarından rahatsız olduklarını belirtirken de bu tutuma yönelik hareket ettikleri görülmektedir:

"kanalının adını değiştirisin :D itsmeduygu değil itsme Ad olsun herkes rahat etsin :D:D:D” [S, V3] 


\subsection{Video İçeriğine İnanmama}

Doğrucular ve Sevmeyenler grubu üyeleri YouTuber'ın marka işbirliği videolarının içeriğine inanmadıklarını belirten ifadeler kullanmışlardır. Ancak gruplar arasında videolara inanmamayı ifade etme biçimi farkılışmaktadır. Doğrucular grup üyelerinin video içeriklerine inanmadıklarını ifade biçimleri şu şekildedir:

"Şimdi bunların hepsini sen mi satın aldın yoksa marka mı gönderdi?" [D, V2]

"Sponsorun yolladığı giysileri böyle bayılarak anlatmak reklamdan başka bir şey değil daha uygun ve kendinize alığınız şeyleri paylaşabilirsiniz" [D, V2]

"Tipik türk youtuber davranislari.. Azicik popüler olunca hemen sponsorlu video yagmuru basliyo. Dürüst oldugundan da ben kendi adıma cok süpheliyim..." [D, V3]

"Duygu hanım, artık çok fazla sponsorlu video çekiyorsunuz. Önceden ben sizi çok beğenerek seyrediyordum halen öyle ama samimiyetinizden şüphe etmeye başlamadım değil bu yüzden. Umarım sponsorlu ürünleri gerçekten beğenerek kullanıyorsunuzdur. Sevgiler." [D, V3]

Doğrucular grup üyelerinin video içeriklerine inanmadıklarını belirtirken direkt olarak YouTuber'a yönelik ifadeler kullandıkları ve video içeriklerine neden inanmadıkları gerekçelendirdikleri ve saygılı bir iletişim biçimini tercih ettikleri görülmüştür. Markanın yer aldığı segment ile ilgili herhangi bir ayrıma gitmeyen Doğrucular, işbirliği videosundan rahatsız olma tavırları ile benzer olarak içeriğin sponsorlu olmasından kaynaklanan bir inanmama tepkisi göstermişlerdir.

Buna karşın Sevmeyenler grubu üyeleri, YouTuber'ın tanıtımını yaptığı markalar konusunda kesinlikle samimi olmadığını düşündüklerini hatta bundan emin olduklarını belirten ifadeler kullanmışlardır. Sevmeyenler grubu üyeleri, video içeriğine inanmadıklarını belirtirken markaların ait oldukları segment farkını da göz önünde bulundurmakta ve ifadelerinde bu ayrıma yer vermektedir. Kendi segmentinden bir marka ile yaptığı işbirliği videosu olan Video 2'de daha ürünleri kullanmamışken nasıl favorisi olduğu hakkında ifadelere rastlanmaktadır. Ayrıca grup, alt segmentteki markanın ürünlerini YouTuber'ın gerçek hayatta kullanmasının mümkün olmadığını, bu yüzden inandırıcı gelmediğini belirtmişlerdir:

“...giymeden nasıl favorisi oluyo onu da çözemedim.” [S, V2]

" milleti kandırıyor o ayakkabıları bir kere bile ayağına sokmus değil buna adım gibi eminim." [S, V2]

“...dudak kalemi için "Dün de bunu kullanmıştım” demesi yapmacıklığı tırmandırmış gerçekten. Dün de onu kullanmadığını biliyoruz hatta koşa koşa gidip silmişsindir o makyajı kesin :D" [S, V3]

"Duygu bunları kullandıktan sonra eminim çöpe atmıştır" [S, V3]

\subsection{YouTuber Marka İșbirliğine Destek Olma}

Diğer gruplardan farklı olarak YouTuber'ı sahiplenme ve olumsuz yorumlara karşı 
koruma konusunda agresif bir tutuma sahip olan Hayranlar grup üyeleri, işbirliği videolarına gelen olumsuz yorumlar karşısında YouTuber'a destek olan ifadeler kullanmakta ve diğer gruplardan gelen yorumlar karşısında YouTuber'ı savunmaktadır. Bununla beraber olumsuz yorum yapan kullanıcılara karşı aşağılayıcı bir üsluba sahiptirler:

“... Yazmış vidyonun altına tanıtım vidyosudur beğenmiyorsanız bir önceki ya da sonrakini izleyebilirsiniz diye. Kezban bunu okumuyor da millete kitap oku tavsiyesi veriyor. Hmpfsss. Yetenekli ve zevklisin bence duygu abla. Aynen devam <3'”' [H, V2]

Hayranlar grup üyelerine karşı daha objektif bir bakış açısına sahip olan üyelerden oluşan Doğrucular grubu da YouTuber'ı diğer grupların olumsuz yorumlarına karşı koruyan ve sahiplenen ifadeler kullanmıştır:

"Şöhretin bedeli;) canını sıkma her kafadan bir ses çıkar..." [D, V2] "Duygu, son 1 haftada 8 video koymus, dört tanesi yani yarısı sponsorlu bence gayet uygun yarı yarıya olmaları ve de sonuçta aldığı kıyafetler kendi seçimi. reklamda olsa giymeyeceği bir şey alınmamış, tebrikler canım güle güle kullan hepsini” [D, V2] "bence sponsorlu video çekmesi ne kadar kanalinin buyudugunu gösterir. her gelenin videosunu cektigini dusunmuyorum ve bu tum bloggerlar icin boyle bence."'” [D, V3]

Doğrucular grubunun ifadelerinden yola çıkarak kanal topluluğunda gözlemlenen destek olma davranışının, işbirliği videolarına inanmama ve bu videolardan rahatsız olma davranışlarına bağlı olarak ortaya çıktığını söylemek mümkündür. İfadelerin diğer kullanıcılara cevap niteliği taşıması bu kanıyı destekler niteliktedir. Aynı zamanda doğrucuların destek olurken dahi saygılı iletişim kurmaya özen gösterdikleri ve gerek YouTuber'a gerekse diğer kullanıcılara niçin destek verdiğini açıklama gayretinde oldukları görülmektedir. YouTuber'ı eleştiren farklı grup üyelerine karşı hayranlar grubunda gözlemlendiği gibi tümden bir reddetme ve aşağılamadan ziyade gelen fikirlerin taşıdığı yanlışlığı ispat etme çabasında olan doğrucular bu nedenle video içeriklerini dikkate alarak sebepler sunmaktadır:

"duygucum yoluna böyle devam et :) drugstore [uygun fiyatlı makyaj malzemeleri için kullanılan bir terim] çıkmış başına bile, ilk önce sana yürüdüler biraz bizden olsan duygu uygun fiyatlı kullanışı ürünler öner bize diye önerdin şimdi bize kendini drugstore ürünler kullanarak soğutma diyorlar eğer böyle yapacaklarsa bırak soğusunlar canım seni seviyorum :)" [D, V3]

Doğrucuların, Avon markası ile gerçekleştirilen işbirliğini (Video 3) eleştiren kullanıcılara karşı YouTuber Duygu Özaslan'ın daha önceki söylemlerini hatırlatmaları göz önüne alındığında kanalın uzun süredir takipçisi olduklarını söylemek mümkündür. Aynı şekilde YouTuber'ın kendi segmentinde yer alan ForeverNew markası ile gerçekleştirdiği işbirliği (Video 2) videosunda yer alan ürünlerin çok pahalı olduğu konusunda içerik üreticisini eleştiren diğer grup üyelerine karşı, doğrucuların kanal topluluğunun yapısı ile ilgili bilgileri sunduktan sonra YouTuber'a destek olduğu görülmektedir: 
"Duygunun tüm takipçileri düşük ya da orta gelirli insanlardan oluşmuyor. Onun alabildiği malzemeleri alabilen insanlar da var. Kimse sizin cebinize uygun vlog çekmek zorunda değil” [D,V2]

\section{6. İșbirliği Videosunu Normal Karșılama (Reklamsız İçerikten Ayırt Etmeme)}

Son olarak hayranlar ve doğrucular grup üyelerinin YouTuber tarafından üretilen marka işbirliği videolarını, kanalda yer alan diğer içeriklerden ayırt etmeme davranışı ortaya koydukları görülmüştür. YouTuber'ın yaptığı her davranışı destekleme eğilimine sahip olan Hayranlar grubunun işbirliği videosuna yönelik kullandığı ifadeler şu şekildedir:

"video süper olmuş her zamanki gibi :D:D" [H,V2]

"yeni video geldiğini görünce çığıık atacaktım neredeyse :D her zamanki gibi çok güzel bir video olmuş" [H, V3]

Doğrucular grubu üyeleri de işbirliği videolarını reklamsız içeriklerden ayırmama davranışını sergilemekte ancak yorumlarında videoların içeriklerine gönderme yapan ifadeler kullanmaktadır:

"çok güzel seçimler güle güle kullan :-)" [D, V2]

"makyaj çok güzel olmuş videoda çok içten olmuş eline sağlık" [D, V3]

\section{Sonuc}

Yapılan analizler sonucunda kendi adı ile makyaj ve lifestyle içeriklere sahip videolar üreten ve YouTube kullanıcıları sınıflandırmasında YouTube ünlüleri kategorisine giren Duygu Özaslan'ın sahip olduğu kanal topluluğunun hayranlar, doğrucular ve sevmeyenler olarak üç gruba ayrıldığı tespit edilmiştir.

Hayranlar ve doğrucular gruplarının aktif bir iletişimi tercih ettikleri ve hemen hemen her konuda yorum yapmaya istekli oldukları görülmüştür. Ancak bu iki grubun aksine sevmeyenler grubunun YouTuber'ı sürekli olarak eleştirme çabası içinde olduğundan bahsedilebilir. Bu nedenle YouTuber'ın kendi segmentinin altında yer alan bir marka ile işbirliği yaptığı takdirde sevmeyenler grubunun YouTuber'ın ilgili markayı kullanmadığına, sadece reklam yapma amacı ile içeriği paylaştığına dair yorumlar yaptıkları belirlenmiştir. YouTuber'ı bir rol model olarak benimseyen hayranlar grubunun, YouTuber'ın tüm davranışlarına destek verdikleri bu nedenle işbirliği yapılan markaya karşı olumlu bir tutum geliştirebilecekleri söylenebilir. Bununla beraber hayranlar grubunu oluşturan üyelerin çoğunun yaş aralığının düşük olması ve grup üyelerinin henüz satın alım gücüne sahip olmaması nedeniyle grup dinamiği içerisinde gelişen olumlu tutumun markaya yönelik kısa vadeli eylemlerden ziyade uzun vadede bir yarar sağlayacağını söylemek mümkündür.

Elde edilen bulgulardan yola çıkarak Duygu Özaslan ile işbirliği yapma niyetinde olan markaların, doğrucular grubu üyelerini hedeflemeleri gerektiği söylenebilir. Diğer gruplara göre belirli bir değerlendirme kriterlerinin olması, YouTuber'a ve videolarda bahsedilen ürünlere daha objektif bir bakış açısı ile yaklaşmaları ve satın alma gücüne sahip olmaları nedeniyle bu grubun işbirliği yapılan markalara kısa vadede geri dönüş sağlaması beklenebilir. 
Markaların işbirliği videoları yaparken göz ardı etmemeleri gereken bir diğer nokta kanal topluluğunun yoğun bir iletişim çabası içerisinde olduğudur. Hayranlar ve doğrucular grubu üyelerinin YouTuber'a ilgili markalar ile ilgili sorular sorduğu ancak soruların ya cevaplanmadığı ya da ilgili sorulara diğer kullanıcılar tarafından cevap verildiği tespit edilmiştir. Başarılı bir YouTube kanal topluluğu oluşturmak için en önemli noktalardan biri etkileșimi sürdürmektir. Etkileşimi sürdürmek ise topluluk üyeleri ile ilişkiler kurmak, kullanıcıların yorumlarına cevap vermek ve geri bildirimleri göz önünde bulundurmak ile mümkündür (Sherman ve Smith, 2013: 324). Bu nedenle yorumlar mümkün olduğunca okunmalı, içerik üreticisi videonun yayınlandığı ilk birkaç saat içerisinde gelen yorumları cevaplamaya dikkat etmelidir. Illk geri bildirimleri veren bu kullanıcılar, sadık topluluk üyelerini temsil etmektedir (YouTube Creator Playbook for Brands, 2015: 80). Gerçek anlamda yararlı bir işbirliğinin söz konusu olabilmesi ve Duygu Özaslan'ın sahip olduğu topluluğun büyüklüğünden yararlanılabilmesi için markaların işbirliği videoları altındaki yorumları takip etmeleri ve kullanıcıların sorularına olabildiğince yanıt vermeleri önemlidir. Bu sayede markaların kanal topluluğu üyelerine, yüksek izlenme oranları ile ulaştıktan sonra kişiselleştirilmiş bir iletişim sunabilmesinin mümkün olacağı ve günümüz pazar ortamında rakiplerinden farklılaşma sağlayacağı söylenebilir.

Topluluklar bir zamanlar sınırlı, yalıtılmış ve homojen olarak görülürken, bugün yüksek oradan birbirine bağlı, heterojen ve anlaşmazlıklarla doludur. YouTube'da hangi topluluk türlerinin daha etkin olduğunu belirlemek için en iyi kaynaklardan biri, YouTube üyeleri arasında gerçekleşen tartışmalar, bir başka deyişle kullanıcıların yorumlarıdır (Strangelove, 2010: 104-105). Yorumlara ve yorum yapan kullanıcılara odaklanma YouTube izleyicisi hakkında derinlemesine bilgi vermektedir (Thelwall vd., 2012: 2). Araştırma sürecinde yapılan literatür taramasında YouTuber - marka işbirliği ve netnografi desenin bir arada kullanıldığı çalışmalara rastlanmamıştır.

YouTube kanal topluluklarının yapısını analiz etmek için yorumların önemli bir veri kaynağı olduğu göz önüne alındığında, netnografinin bu alanda gerçekleştirilecek nitel çalışmalarda araştırma deseni olarak tercih edilmesi araştırmacılara derinlemesine analiz yapabilme imkânı sağlayacaktır. Farklı YouTube içerik üreticilerinin sahip oldukları kanal toplulukların yapısının detaylı olarak incelendiği araştırmaların, netnografi ve YouTuber-marka işbirliği konusundaki kısıtlı olan literatüre ve bir içerik üretim sitesinden yanı sıra kültürel değişimin etkilerinin en çok hissedildiği alanlardan biri olan YouTube'un reklamcılık açısından etkili yönlerinin belirlenmesine ciddi katkılar sağlayacağı düşünülmektedir.

Duygu Özaslan isimli makyaj kanalı, Türkiye'de faaliyet gösteren makyaj ve lifesytle içerik üreten YouTube kanalları arasında en çok izleme ve abone sayısına sahiptir. Netnografik araştırma için elverişli bir ortamın yaratılması önemlidir. Bu noktada videolara gelen yorum sayısının yüksek ve video izleme trafiğinin yoğun olması ilgili kanalın tercih edilmesinde etken olmuştur. YouTube kanal topluluğunun özelliklerinin ve üye tiplerinin belirlenebilmesi için üç videoda yer alan 4 Ekim 2015 - 11 Mayıs 20151.502 yorumun her biri analiz edilmiştir. Ancak raporlaştırma sürecinde, yalnızca araştırmanın problemlerine cevap verecek olan "işbirliğine yönelik tavırlar" kategorisindeki destek olma, rahatsız olma, inanmama ve normal karşılama kodları dikkate alınmıştır. Bununla birlikte, grupların farklı içerikler karşısında sergiledikleri tutumları inceleyebilmek için en az iki videoda aynı kod ile ilişkilendirilebilen yorumlar incelenmiştir. Çalışmanın nitel bir araştırma olması nedeniyle elde edilen bulguları, 
belirli bir evrene genellemek mümkün değildir. Bulgular, netnografi aracılığıyla incelenen Duygu Özaslan isimli içerik üreticisinin sahip olduğu YouTube kanalının topluluğu ile sınırlıdır.

\section{Kaynakça}

Burgess, Jean ve Green, Joshua (2009). "The Entrepreneurial Vlogger: Participatory Culture Beyond The Professional-Amateur Divide." The YouTube Reader. Snickars, Pelle ve Vonderau, Patrick (der.) içinde. Stockholm: National Library of Sweden/Wallflower. 89-107.

Chau, Clement (2010). "YouTube as a Participatory Culture." New Directions for Youth Development, 2010(128): 65-74.

Cunff, Anne-Laure (2015). “içerik Pazarlamacılarına Yönelik Üç YouTube İpucu.» https:// www.thinkwithgoogle.com/int//tr-tr/article/icerik-pazarlamacilarina-yonelik-uc-youtube-ipucu/. 05.05.2016.

Dyck, Fons Van (2014). Yeni Nesil Reklamcılık. Çev., Volkan Eke. İstanbul: The.

Ertürk, Yıldız Dilek ve Ertem Eray, Tuğçe (2015). "Arama Motorları ve Sosyal Paylaşım Ağları Üzerinden Kullanıcı Tutumlarına Göre İnternet Reklamları.” Yeni Medya ve Reklam. Abdullah Özkan, Nilnur Tandaçgüneş ve Betül Önay Doğan (der.) içinde. İstanbul: Derin. 67-109.

"Gül Kurusu Makyaj I 2000 Big\&False Lash Maskara Hediye." (08.10.2015). https://www.youtube. com/watch?v=2JcarFNJ7B0. 11.05. 2016.

"HD Makyaj I Fotoğraf, Kamera Makyajı." (07.10.2015). https://www.youtube.com/ watch?v=rtE9OXqdjGE. 11.05. 2016.

Holmbom, Mattias (2015). "The YouTuber: A Qualitative Study of Popular Content Creators." https://www.paypal.com. 25.07.2016.

Jenkins, Henry (2001, Haziran). "Convergence? I Diverge." Technology Review, 104(5): 93.

Jenkins, Henry, Purushotma, Ravi, Weigel, Margeret, Clinton, Katie, ve Robison, Alice (2006). "Confronting the Challenges of Participatory Culture: Media Education for the 21st century". An Occasional Paper on Digital Media and Learning. John D. and Catherine T. MacArthur Foundation.

Kaplan, Andreas ve Haenlein, Michael (2010). "Users Of The World, Unite! The Challenges and Opportunities Of Social Media." Business Horizons(53): 59-68.

Kozinets, Robert (2010). "Netnografi: Pazarlamacının Gizli Silahı." http://kozinets.net/wp-content/ uploads/2012/01/netnography-turkish.pdf. 05.05.2016.

Lange, Patricia (2007). "Commenting on Comments: Investigating Responses to Antagonism on YouTube." Tampa, Florida: Society for Applied Anthropology Conference: 1-26.

Larson, Kim (2016). "YouTube İçerik Stratejisi Oluşturma: Lessons From Google BrandLab." https://www.thinkwithgoogle.com/int//tr-tr/article/youtube-icerik-stratejisi-olusturma-lessons-fromgoogle-brandlab/. 02.02.2017. 
Mayfield, Antony (2008). "What is Social Media." iCrossing, e-book, http://www.icrossing.com/uk/ sites/default/files_uk/insight_pdf_files/What\%20is\%20Social\%20Media_iCrossing_ebook.pdf. 05.11.2016.

Mueller, Bryan (2014). Participatory Culture on YouTube: A Case Study of the Multichannel Network Machinima. London: MEDIA@LSE MSc.

Özgüven, Nihan (2015). «Sosyal Ağlarda Markalaşma: Dijital Ortamlarda Reklam Uygulama Örnekleri.» Yeni Medya ve Reklam. Abdullah Özkan, Nilnur Tandaçgüneş, ve Betül Önay Doğan (der.) içinde. İstanbul: Derin. 111-131.

Sherman, Aliza ve Smith, Danielle Elliott (2013). Social Media Engagement For Dummies. New Jersey: John Wiley \& Sons.

Strangelove, Michael (2010). Watching YouTube: Extraordinary Videos By Ordinary People. Canada: University of Toronto.

Thelwall, Mike, Sud, Pardeep ve Vis, Farida (2012). "Commenting On YouTube Videos: From Guatemalan Rock To El Big Bang." Journal of the American Society for Information Science and Technology, 63(3): 616-629.

"The YouTube Creator Playbook for Brands." (2015). https://think.storage.googleapis.com/docs/ creator-playbook-for-brands_research-studies.pdf. 01.06.2016

The World of YouTube (2015). "Part I: The "Coming of Age" of a YouTube Star." https:// s3.amazonaws.com/grapevine_media/grapevine_worldofyoutube_2015.pdf . 01.06.2016

Varnalı, Kaan (2013). Dijital Kabilelerin İzinde. İstanbul: MediaCat.

"Yeni Sezon Alışverişim I Forever New I ad." (04.10.2015). https://www.youtube.com/ watch?v=DfvBhj6cln4. 11.05. 2016

Yeygel Çakır, Sinem (2015). "Kullanıcı Reklamcı Mı Oluyor?: Sosyal Medyada Etkileşimciliğin Gücü ve Kullanıcı Merkezli İçerik Üretimi." Yeni Medya ve Reklam. Abdullah Özkan, Nilnur Tandaçgüneş, ve Betül Önay Doğan (der.) içinde. İstanbul: Derin. 213-252.

Yıldırım, Ali ve Şimşek, Hasan (2013). Sosyal Bilimlerde Nitel Araştırma Yöntemleri. Ankara: Seçkin.

"YouTube Yıldızları Neden Geleneksel Ünlülerden Daha Etkili?." (2016). https://www. thinkwithgoogle.com/int//tr-tr/infographic/youtube-yildizlari-neden-geleneksel-unlulerden-dahaetkili/.01.06.2016.

https://en.wikipedia.org/wiki/You_(Time_Person_of_the_Year). 01.05.2016. http://www.boomsocial.com/Youtube/UlkeSektor/turkey/tumu/.11.05.2016. 